\title{
Kualitas Semen Sapi Brahman pada Persentase Tris Kuning Telur yang Berbeda
}

\author{
Quality of Brahman Semen in Different Yellow Egg Tris Percentage \\ R. Novita, T. Karyono, dan Rasminah \\ Fakultas Pertanian Prodi Peternakan Universitas Musi Rawas \\ Jl. Komplek Perkantoran Pemkab MURA Kel.Air kuti I. Lubuklinggau 31628 \\ Corresponding Author: teguhkaryono89@yahoo.co.id
}

\begin{abstract}
This study determined the quality of Brahman cattle semen on the percentage of different yolk tris. This research held at UPTD Artificial Insemination Center (BIB) Sembawa, Banyuasin district, Sumsel. This research was conducted in three months. The method used was experimental method using Completely Randomized Design (CRD), which was arranged non factorial using 6 treatments and 4 replications. As for treatment in this research were K1:5\% Yellow egg Tris + Spermatozoa $1 \mathrm{ml}, \mathrm{K} 2: 10 \%$ Yellow egg Tris + Spermatozoa $1 \mathrm{ml}, \mathrm{K} 3: 15 \%$ Yellow egg Tris + Spermatozoa $1 \mathrm{ml}, \mathrm{K} 4: 20 \%$ Yellow egg Tris + Spermatozoa 1 $\mathrm{ml}, \mathrm{K} 5: 25 \%$ Yellow egg Tris + Spermatozoa $1 \mathrm{ml}$, K6 : 30\% Yellow egg Tris + Spermatozoa $1 \mathrm{ml}$. To determine the effect of treatment, the data were obtained by analysis of variance (Anova) and further testing of HSD (real honest difference). The results showed that Brahman cattle semen quality on the percentage of different yolk tris showed very significant effect $(\mathrm{P}<0.01)$ on the percentage of spermatozoa viability, individual motility, spermatozoa concentration; yet, no significant effect $(\mathrm{P}>0.05)$ on percentage of spermatozoa abnormalities. The percentage of different yolk trises gave the best results $\mathrm{K} 4(20 \%)$ on the egg yolk tris treatment on percentage parameters of spermatozoa viability, individual motility and spermatozoa concentration.
\end{abstract}

Key words : Spermatozoa, egg yolk, brahman cow.

\begin{abstract}
ABSTRAK
Tujuan dari penelitian ini adalah mengetahui kualitas semen sapi Brahman pada persentase tris kuning telur yang berbeda. Penelitian ini dilaksanakan di UPTD Balai Inseminasi Buatan (BIB) Sembawa, Kabupaten Banyuasin, Sumsel dan dilaksanakan pada bulan September sampai dengan November 2017. Penelitian Kualitas Semen Sapi Brahman pada Presentasi Tris Kuning Telur yang Berbeda menggunakan metode eksperimental Rancangan Acak Lengkap (RAL) non faktorial 6 perlakuan dan 4 kali ulangan. Adapun perlakuan dalam penelitian ini adalah K1 : 5\% Tris Kuning Telur + Spermatozoa $1 \mathrm{ml}, \mathrm{K} 2: 10 \%$ Tris Kuning Telur + Spermatozoa $1 \mathrm{mi}, \mathrm{K} 3$ : 15\% Tris Kuning Telur + Spermatozoa $1 \mathrm{ml}, \mathrm{K} 4: 20 \%$ Tris Kuning Telur + Spermatozoa $1 \mathrm{ml}, \mathrm{K} 5: 25 \%$ Tris Kuning Telur + Spermatozoa $1 \mathrm{ml}$, K6 : 30\% Tris Kuning Telur + Spermatozoa $1 \mathrm{ml}$. Data yang diperoleh hasil dari pengaruh perlakuan diolah dengan metode analisis ragam (ANOVA) dan uji lanjut BNJ. Hasil penelitian kualitas semen sapi Brahman pada persentase tris kuning telur yang berbeda menunjukkan berpengaruh sangat nyata $(\mathrm{P}<0,01)$ terhadap Persentase Viabilitas Spermatozoa, Motilitas Individu, Konsentrasi Spermatozoa dan berpengaruh tidak nyata $(\mathrm{P}>0,05)$ terhadap Persentase Abnormalitas Spermatozoa. Persentase tris kuning telur yang berbeda memberikan hasil terbaik pada perlakuan K4 (20\%) tris kuning telur pada parameter viabilitas spermatozoa, motilitas individu dan konsentrasi spermatozoa.
\end{abstract}

Kata kunci :Spermatozoa, tris kuning telur, sapi Brahman.

\section{PENDAHULUAN}

Sapi Brahman adalah salah satu ternak penghasil daging yang unggul dan sudah dikenal oleh masyarakat secara umum. Salah satu upaya untuk memenuhi kebutuhan konsumsi daging pada masyarakat Indonesia adalah dengan peningkatan produksi daging.
Peningkatan kualitas Sapi Brahman di Indonesia dapat dilakukan dengan perbaikan manajemen pemeliharaan ternak dan peningkatan mutu genetik dengan Inseminasi Buatan pada ternak potong (Rianto, 2004 )

Sapi Brahman adalah keturunan sapi Zebu atau Bos indicus yang berkembang pesat di Amerika Serikat yang beriklim 
tropis, kemudian Sapi Brahman dikembangbiakkan di Australia dan New Zeeland dengan meningkatkan mutu genetiknya. Sapi Brahman kemudian di ekspor ke beberapa negara termasuk di Indonesia (Susilawati et al., 2003)

Salah satu bentuk bioteknologi dalam bidang reproduksi ternak adalah Inseminasi Buatan (IB) yang memanfaatkan pejantanpejantan unggul untuk diambil spermatozoanya dan disimpan dalam bentuk straw. Kemudian sebagai bioteknologi rangkaian proses inseminasi buatan akan meningkatkan kualitas genetik dari seekor ternak (Kartasudjana, 2001).

Cairan suspensi seluler hasil sekresi kelenjar assesoris pada saluran reproduksi Sapi pejantan yang mengandung spermatozoa disebut Semen. Tingkat keberhasilan Inseminasi Buatan dipengaruhi oleh beberapa faktor seperti Inseminator, kualitas semen, thawing dan pakan. Semen segar akan menghasilkan tingkat keberhasilan S/C lebih baik dibandingkan dengan semen beku (Hafez, 2000). Untuk meningkatkan volume semen, dan masa semen serta menjaga morbilitas spermatozoa dilakukan dengan tindakan pengenceran semen pada kondisi dibawah atau diatas titik beku (Rusdin, 2000)

Salah satu bahan Pengenceran semen adalah tris kuning telur yang berfungsi sebagai sumber energi, melindungi dari kejutan dingin serta melindungi spermatozoa dalam proses pengenceran semen (Nilawati, 2011). Fungsi Tris kuning telur sebagai penyangga atau buffer, menstabilkan $\mathrm{pH}$, mempertahankan tekanan osmotik dan keseimbangan elektrolit, melindungi sprematozoa dari kejutan dingin (Cold shock) yang merupakan larutan yang mengandung fruktosa dan asam sitrat (Hoesni, 1997).

Tris Kuning telur merupakan larutan menyangga yang baik memiliki tekanan osmotik, elektrolit dan keseimbangan $\mathrm{pH}$ yang baik (Affandhy et al., 2003). Namun penggunaan pengencer tris perlu ditambahkan juga kuning telur, karena di dalam kuning telur terdapat lipoprotein dan lesitin yang dapat mengurangi efek coldshock bagi spermatozoa, sehingga kerusakan pada saat pengenceran, pendinginan dan pembekuan berkurang (Salisbury dan Van Demark, 1985).

\section{METODE PENELITIAN}

Penelitian ini telah dilaksanakan di UPTD Balai Inseminasi Buatan (BIB) Sembawa, Kabupaten Banyuasin, Sumatra Selatan pada bulan September sampai dengan November 2017. Penelitian Kualitas Spermatozoa Sapi Brahman dengan Tris Kuning Telur menggunakan Rancangan Acak Lengkap (RAL) non faktorial menggunakan 6 taraf dengan 4 kali ulangan. Adapun taraf perlakuan yang akan di ujicobakan sebagai berikut :

\section{$\mathrm{K} 1=5 \%$ Tris kuning telur + spermatozoa $1 \mathrm{ml}$ \\ $\mathrm{K} 2=10 \%$ Tris kuning telur + spermatozoa $1 \mathrm{ml}$ \\ $\mathrm{K} 3=15 \%$ Tris kuning telur + spermatozoa $1 \mathrm{ml}$ \\ $\mathrm{K} 4=20 \%$ Tris kuning telur + spermatozoa $1 \mathrm{ml}$ $\mathrm{K} 5=25 \%$ Tris kuning telur + spermatozoa $1 \mathrm{ml}$ $\mathrm{K} 6=30 \%$ Tris kuning telur + spermatozoa $1 \mathrm{ml}$}

\section{Cara Kerja}

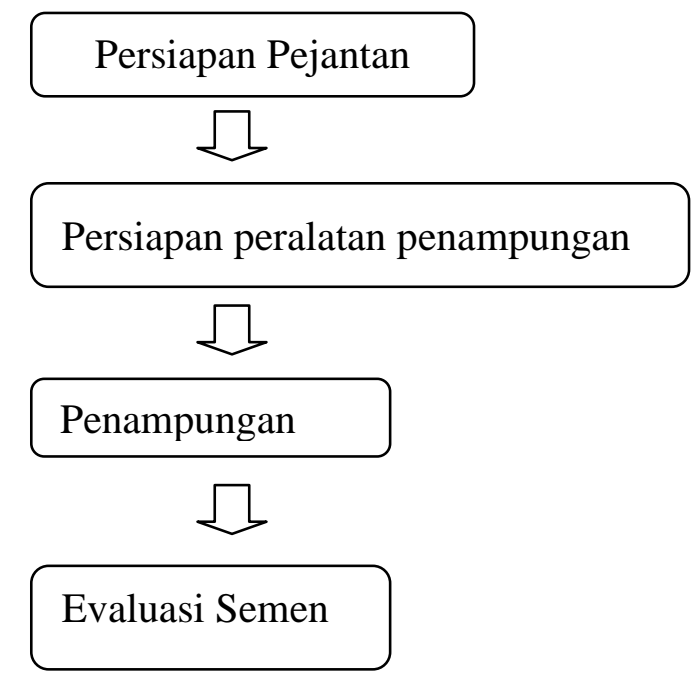

\section{Pemeriksaan Mikroskopis Gerakan Massa}

Pada pemeriksaan spermatozoa apabila terdapat mobilitas gerakan massa sperma berkelompok menuju satu arah seperti gelombang awan tipis bergerak cepat atau lambat. 
Penilaian gerakan massa :

- Sangat baik (+++), seperti gelombang awan tebal, gelap akan turun hujan bergerak aktif berpindah-pindah.

- Baik (++), seperti gelombang awan tipis, berkabut dan gerakan lamban.

- Lumayan (+), tidak terlihat gelombang awan atau kabut melainkan mobilitas individual aktif progresif.

- Buruk (nekrosperrmia/0), tidak ada gerakan individu atau mobilitas individu.

\section{Gerakan Individual / Motilitas}

Motilitas individu spermatozoa ditentukan dengan nilai 0 sampai dengan 5 seperti :

0 : Jika Spermatozoa mati atau tidak ada pergerakan

1: Jika mobilitas spermatozoa berputarputar di tempat.

2: Jika mobilitas atau Gerakan spermatozoa melingkar-melingkar

3: Jika terdapat gerakan masa seperti awan tipis $50 \%$ sampai $80 \%$ artinya spermatozoa bergerak progresif

4: Jika pergerakan spermatozoa progresif dan gesit seperti awan tebal membentuk gelombang sperma hidup $90 \%$

5: Jika gerakan spermatozoa sangat cepat progresif, seperti awan hitam yang bergerak cepat artinya $100 \%$ sperma motil.

\section{Konsentrasi Spermatozoa}

Metode penghitungan konsentrasi spermatozoa, yaitu :

Penghitungan dengan Spektro Photometer / SDM5 Photometer.

\section{Pengenceran Semen}

Setelah semen layak untuk diencerkan, segera dilakukan pengenceran Bahan pengencer banyak jenisnya, tetapi yang dipakai di BIB Sembawa yaitu Tris Kuning Telur. Pengencer semen dengan menggunakan perlakuan $\mathrm{K} 1, \mathrm{~K} 2, \mathrm{~K} 3, \mathrm{~K} 4$, K5 dan K6 mengandung tris kuning telur masing-masing $5 \%$ tris kuning telur, $10 \%$ tris kuning telur, $15 \%$ tris kuning telur, $20 \%$ tris kuning telur, 25\% tris kuning telur, 30\% tris kuning telur.

\section{Filling dan Sealing}

Setelah semen diencerkan langsung dilakukan Filling dan Sealing (Proses pengisian semen yang telah diencerkan dan penjepitan straw) dilakukan didalam cool top yang bersuhu $5^{0} \quad \mathrm{C}$ menggunakan semiautomatic filling and sealing machine.

\section{Ekuilibrasi / Pendinginan}

Waktu ekuilibrasi adalah periode yang diperlukan spermatozoa sebelum pembekuan untuk menyesuaikan diri dengan pengencer supaya pada waktu pembekuan dalam N2 cair kematian spermatozoa dapat dikurangi. Waktunya biasanya 3-5 jam dengan suhu $5^{0} \mathrm{C}$ di dalam cool top.

\section{Proses Freezing}

Proses freezing merupakan proses penurunan suhu secara bertahap sebelum disimpan didalam N2 cair. Susun straw yang telah dikemas diatas rak kemudian diletakkan diatas N2 Cair $( \pm 1 \mathrm{~cm}$ diatas permukaan $\mathrm{N} 2$ cair) sampai suhunya $-140^{\circ} \mathrm{C}$ selama 10 menit. Setelah itu segera straw dimasukkan ke dalam goblet dan dibekukan dengan menempatkan semen di dalam N2 cair dan disimpan dalam container. Suhu N2 cair disini adalah $-196{ }^{\circ} \mathrm{C}$.

\section{Penyimpanan Semen Beku}

Semen yang telah dibekukan kemudian disimpan di N2 cair pada container.

\section{Evaluasi Semen setelah Pembekuan (after Thawing Test)}

Cara melakukan test Post thawing Motility (Motilitas setelah diencerkan kembali)

1. Ambil straw dari goblet, masukkan dalam air hangat sekitar 30 detik.

2. Potong kedua ujung straw, teteskan semen ke atas objek glass, tutup dengan cover glass. 
3. Periksa dibawah mikroskop dengan pembesaran $10 \times 10$.

\section{HASIL DAN PEMBAHASAN}

\section{Persentase Viabilitas Spermatozoa pada Persentase Tris Kuning Telur yang Berbeda}

Berdasarkan hasil analisis ragam persentase viabilitas semen diketahui bahwa persentase tris kuning telur yang berbeda menunjukkan pengaruh yang sangat nyata $(\mathrm{P}<0,01) \quad$ terhadap kualitas semen sapi Brahman dengan persentase tris kuning telur yang berbeda. Pada perlakuan K4 (20\%) memberikan nilai tertinggi atau terbaik dalam kualitas pengenceran semen sapi Brahman dengan tris kuning telur yang berbeda yaitu dengan nilai $76,00 \%$. Hal ini disebabkan karena komposisi tris kuning telur lebih lengkap mengandung asam-asam amino, karbohidrat, vitamin dan mineral serta terdapat unsur lain yang dapat berfungsi mempertahankan daya hidup spermatozoa, terutama lipoprotein, lecitin dan fruktosa yang berguna sebagai pelindung spermatozoa dari kerusakan selubung sel spermatozoa akibat cold shock, merupakan pengencer yang lebih lengkap dibandingkan dengan pengencer lainnya sehingga menghasilkan daya tahan hidup yang lebih lama. Hal ini sesuai dengan pendapat Werdhany (1999) yang menyatakan bahwa meskipun lesitin dan lipoprotein berguna untuk melindungi spermatozoa dari cekaman dingin, akan tetapi dengan bertambah lamanya penyimpanan, akan terjadi penurunan
Nilai terendah yaitu pada persentase tris kuning telur $\mathrm{K} 1$ (5\%) dengan nilai $54,13 \%$ dalam viabilitas spermatozoa sapi Brahman. Hal ini dapat disebabkan karena perubahan suhu yang drastis, dari suhu $5{ }^{\circ} \mathrm{C}$ menjadi $-140{ }^{\circ} \mathrm{C}$. Perubahan suhu drastis akan meyebabkan kerusakan spermatozoa yang disebabkan karena cold shock, proporsi zat pelindung lesitin dan lipoprotein yang terkandung dalam setiap level penambahan kuning telur adalah berbeda. Kerusakan spermatozoa akan menyebabkan kematian pada spermatoza. Menurut White (1993), menyatakan bahwa penyebab cold shock adanya perubahan fosfolipid pada membran plasma sel dari bentuk cair ke bentuk gel dibawah temperatur $20{ }^{\circ} \mathrm{C}$ yang berakibat kerusakan membran plasma sel.

\section{Motilitas Spermatozoa pada Persentase Tris Kuning Telur yang Berbeda}

Berdasarkan hasil analisis ragam menunjukkan bahwa motilitas individu semen pada persentase tris kuning telur yang berbeda memberikan pengaruh sangat nyata $(\mathrm{P}<0,01)$ terhadap motilitas individu spermatozoa. Hal ini di sebabkan karena persentase tris kuning telur memberikan perlindungan sehinggaa pengaruh kerusakan sel akibat cekaman dingin (cold shock) dapat dicegah. Penambahan tris kuning yang tepat memberikan perlindungan berupa memodifikasi kristal-kristal es yang terbentuk selama proses pembekuan, sehingga kerusakan organ-organ sel spermatozoa dapat dihindari (Siswanto, 2006).

kualitas spermatozoa.

Tabel 1. Hasil analisis ragam kualitas semen sapi Brahman pada persentase tris kuning telur yang berbeda.

\begin{tabular}{lll}
\hline Peubah yang diamati & Fhitung & KK $(\%)$ \\
\hline Persentase viabilitas spermatozoa & $8,10^{* *}$ & 8,31 \\
Motilitas individu & $10,80^{* *}$ & 14,14 \\
Persentase abnormalitas spermatozoa & $1,50^{\text {tn }}$ & 18,35 \\
Konsentrasi spermatozoa & $11,81^{* *}$ & 11,54
\end{tabular}

Keterangan : P : Persentase Tris Kuning Telur, ** Nyata, KK : Koefisien Keragaman 
Pada penelitian ini menujukkan persentase motilitas individu yang tertinggi yaitu pada perlakuan K4 (20\%) yaitu dengan nilai sebesar 36,25\%. Perlakuan K4 (20\%) tris kuning telur mampu memberikan nutrisi bagi metabolisme spermatozoa dan melindungi lebih lama dari pencencer lainnya. Hal ini sesuai pendapat Ducha et al. (2013) yang menyatakan bahwa untuk mempertahankan motilitas spermatozoa sapi Brahman yang terbaik menggunakan pengenceran tris kuning telur 20\%. Hal ini sependapat dengan Graham dan Foote, 1987 dalam Ducha et al. (2013) pengencer yang mengandung tris kuning telur 20\% memberikan hasil motilitas terbaik spermatozoa sapi Brahman.

Tabel 2. Data persentase viababilitas spermatozoa, motilitas individu, persentase abnormalitas spermatozoa dan konsentrasi spermatozoa setiap perlakuan

\begin{tabular}{|c|c|c|c|c|c|c|c|c|}
\hline \multirow{2}{*}{$\begin{array}{l}\text { Peubah } \\
\text { diamati }\end{array}$} & \multicolumn{6}{|c|}{ Perlakuan } & \multicolumn{2}{|c|}{$\mathrm{BNJ}$} \\
\hline & K1 & $\mathrm{K} 2$ & K3 & K4 & K5 & K6 & $5 \%$ & $1 \%$ \\
\hline $\begin{array}{c}\text { Viabilitas } \\
\text { sepermatozoa } \\
(\%)\end{array}$ & $54,13^{\mathrm{aA}} \pm 3,82$ & $61,00^{\mathrm{aA}} \pm 4,95$ & $61,75^{\mathrm{abA}} \pm 6,84$ & $76,00^{\mathrm{cB}} \pm 3,76$ & $67,88^{\mathrm{bAB}} \pm 5,42$ & $60,38^{\mathrm{aA}} \pm 6,16$ & 11,80 & 14,72 \\
\hline $\begin{array}{c}\text { Motilitas } \\
\text { individu (\%) }\end{array}$ & $17,50^{\mathrm{aA}} \pm 6,12$ & $25,63^{\mathrm{abA}} \pm 4,27$ & $26,88^{\mathrm{bAB}} \pm 2,39$ & $36,25^{\mathrm{cB}} \pm 1,44$ & $30,00^{\mathrm{bB}} \pm 4,08$ & $24,38^{\mathrm{aA}} \pm 2,39$ & 8,48 & 10,58 \\
\hline $\begin{array}{c}\text { Abnormalitas } \\
\text { spermatozoa } \\
(\%)\end{array}$ & $12,88 \pm 0,48$ & $12,00 \pm 3,14$ & $16,25 \pm 3,01$ & $15,13 \pm 3,35$ & $13,38 \pm 2,63$ & $13,50 \pm 1,22$ & - & - \\
\hline $\begin{array}{c}\text { Konsentrasi } \\
\text { spermatozoa } \\
\text { (juta) }\end{array}$ & $800^{\mathrm{aA}} \pm 0,00$ & $1400^{\mathrm{cB}} \pm 0,00$ & $1350^{\mathrm{bcB}} \pm 57,74$ & $1400^{\mathrm{cB}} \pm 0,00$ & $1250^{\mathrm{bB}} \pm 288,7$ & $1050^{\mathrm{abAB}} \pm 173,21$ & 313,04 & 390,43 \\
\hline
\end{tabular}

Selanjutnya dinyatakan bahwa persentase motilitas individu spermatozoa yang memenuhi kriteria nantinya akan digunakan untuk inseminasi buatan pada ternak sapi Brahman untuk layak digunakan atau tidak layak digunakan. Hasil penelitian gerakan massa adalah ++ (gerak baik). Arifiantini et al. (2005), menyatakan bahwa penilaian gerakan massa spermatozoa ++ (gerak baik) ini sudah memenuhi standar.

Persentase motilitas individu yang terendah pada perlakuan K1 $(5 \%)$ yaitu

\section{Persentase Abnormalitas Spermatozoa pada Persentase Tris Kuning Telur yang Berbeda}

Berdasarkan hasil analisis ragam menunjukkan bahwa persentase tris kuning telur berbeda tidak nyata terhadap abnormalitas spermatozoa. Hal ini disebabkan perbedaan tidak nyata pada persentase tris kuning telur memberikan persentase abnormalitas spermatozoa yang sama baik terhadap kualitas spermatozoa yang nantinya akan layak digunakan untuk inseminasi buatan pada ternak sapi Brahman. dengan nilai sebesar $17,50 \%$ pada sapi Brahman. Volume pengencer semakin tinggi maka motilitas semakin turun. Perbedaan motilitas pada semen sapi Brahman yang diencerkan dengan volume kuning telur yang berbeda di duga di sebabkan medium plasma semakin kental, yang berakibat motilitas semakin menurun. Sesuai dengan pendapat Herdis (2005) menyatakan bahwa proses pengolahan dan penyimpanan akan menyebabkan perubahan fisik pada semen yang mempengaruhi motilitas spermatozoa Hal ini sesuai Badan Standardisasi Nasional Indonesia /BSNI (2005) menyatakan bahwa semen sapi memiliki morfologi abnormalitas baik primer maupun sekunder di bawah $20 \%$. Dari hasil analisis ragam pada penelitian ini abnormalitas spermatozoa masih sesuai dengan standar SNI yaitu di bawah $20 \%$. Hal ini sesuai dengan pendapat Alawiyah dan Hartono (2006) yang menyatakan bahwa abnormalitas spermatozoa dinyatakan tidak layak digunakan bila persentasenya lebih dari $20 \%$.

Pada penelitian ini menunjukkan persentase abnormalitas spermatozoa 
tertinggi yaitu pada perlakuan K3 (15\%) dengan nilai $16,25 \%$ pada sapi Brahman. Hal ini disebabkan karena semakin banyak tris kuning telur dan perlakuan bisa menyebabkan stres untuk spermatozoa tersebut, sehingga spermatozoa tidak mampu melawan masa kritis selama tris kuning telur yang banyak, spermatogenesis dari ternak tersebut dan perlakuan semen setelah ejakulasi, seperti penanganan semen segar, pencampuran semen dengan pengencer dan pada saat pembuatan ulasan. Lamanya waktu penyimpanan juga mempengaruhi jumlah spermatozoa abnormalitas. Sesuai dengan pendapat Solihati dan Kune (2008) bahwa semakin lama waktu penyimpanan, maka peresentase abnormalitas akan semakin tinggi.

Persentase abnormalitas spermatozoa yang terendah pada perlakuan K2 (10\%) yaitu dengan nilai $12,00 \%$ pada sapi Brahman. Pengaruh tris kuning telur yang berbeda memberikan perlindungan pada membran spermatozoa sehingga abnormalitas spermatozoa dapat menurun serta adanya fungsi dari kuning telur yang bekerja melindungi dan menjaga selubung lipoprotein dan sel spermatozoa. Hal ini sesuai dengan pendapat Parera et al, (2009) yang menyatakan bahwa tris kuning telur memberikan hasil yang baik karena kerusakan sel dan abnormalutas akan meningkat saat pendinginan berlangsung tris kuning telur akan melindungi dan mempertahankan integritas sebelum spermatozoa karena adanya lisitin dan lipoprotein walaupun perlakuan K2 memberikan hasil yang lebih kecil tetapi secara keseluruhan parameter pengamatan memberikan pengaruh yang berbeda tidak nyata terhadap persentase abnormalitas spermatozoa.

Abnormalitas spermatozoa adalah penyimpangan morfologis dari bentuk normal spermatozoa. Perbedaan antara spermatozoa abnormal dan spermatozoa yang normal terbentuk pada waktu spermatogenesis dan abnormal sebagai akibat dari perakuan semen (Aminasari, 2009).

\section{Konsentrasi Spermatozoa pada Persentase Tris Kuning Telur yang Berbeda}

Berdasarkan hasil analisis ragam persentase konsentrasi semen segar pada sapi Brahman menunjukkan berpengaruh sangat nyata. Hal ini di sebabkan karena persentase tris kuning telur yang berbeda pada setiap perlakuan sehingga dapat memberikan pengaruh terhadap pemeriksaan kualitas persentase konsentrasi spermatozoa yang nantinya di gunakan untuk Inseminasi Buatan. Sesuai dengan pendapat Toelihere (1985) kandungan kuning telur terdiri dari lipoprotein dan lechitin berfungsi untuk daya tahan dan melindungi selubung lipoprotein dari sel spermatozoa dan mencegah cold shock. Persentase tris kuning telur yang ditambahkan pada spermatozoa memberikan pengaruh pada konsentrasi spermatozoa yang akan dibuat untuk inseminasi buatan (IB).

Konsentrasi spermatozoa pada perlakuan $\mathrm{K} 2$ dan $\mathrm{K} 4$ dengan persentase tris kuning telur $10 \%$ dan $20 \%$ memberikan nilai tertinggi dalam kualitas pengencer semen sapi Brahman dengan nilai 1400 juta spermatozoa. Hal ini disebabkan karena penambahan persentase tris kuning telur pada perlakuan K2 dan K4 memberikan kombosisi terbaik karena pada tris kuning telur mengandung lipoprotein dan lichitin yang sama baik. Hal ini sesuai dengan pendapat Garner dan Hafez, (2008) bahwa semen sapi Brahman konsentrasinya berkisar 1000-1800 juta spermatozoa tiap mililiter atau 800-2000 juta spermatozoa tiap mililiter.

Pada perlakuan K1 dengan persentase tris kuning telur 5\% dengan hasil konsentrasi senilai 800 juta spermatozoa sapi Brahman. Hal ini disebabkan karena pemberian tris kuning telur 5\% pada semen sapi Brahman menyebabkan konsentrasi spermatozoa lebih rendah di bandingkan dengan perlakuan lain. Hal ini sesuai dengan pendapat Ismaya (2014), bahwa konsentrasi spermatozoa di pengaruhi oleh volume spermatozoa, libido, kedewasaan sapi jantan serta faktor lingkungan seperti pakan dan kesehatan dan bahan pengencer yang ditambahkan. 


\section{KESIMPULAN}

Berdasarkan hasil penelitian dapat disimpulkan bahwa persentase tris kuning telur yang berbeda memberikan hasil terbaik pada perlakuan K4 (20\%) tris kuning telur pada parameter viabilitas spermatozoa, motilitas individu dan konsentrasi spermatozoa.

\section{DAFTAR PUSTAKA}

Aminasari, P. D. 2009. Pengaruh Umur Pejantan terhadap Kualitas Semen Beku Sapi Limousin. Jurnal Fakultas Peternakan Universitas Brawijaya. Malang.

Affandhy, L. 2003. Pengaruh Penambahan Cholesterol dan Kuning Telur di dalam Bahan Pengencer Tris-Sitrat dan Air Kelapa Muda terhadap Kualitas Semen Cair Sapi Potong. hlm. 77-83. Prosiding Seminar Nasional Teknologi Peternakan dan Veteriner, Bogor, 2930 September 2003.

Alawiyah, D., dan M. Hartono. 2006. Pengaruh penambahan vitamin E dalam bahan pengencer sitrat kuning telur terhadap kualitas semen beku kambing Boer. J. Indon.Trop. Anim. Agric. 31(1): 8-14.

Arifiantini, L., T.L. Yusuf, dan N. Graha. 2005. Longivitas dan recovery rate pasca thawing semen beku sapi Friesian Holstein menggunakan bahan pengencer yang berbeda. Buletin Peternakan 29(2): 57-61, ISSN : 01264400 .

Badan Standardisasi Nasional Indonesia. (BSNI). 2005. Semen Beku Sapi. SNI 014869.1-2005. BSN. Jakarta.

Ducha, N., T. Susilawati, Aulanni'am, dan S. Wahyuningsih. 2013. Motilitas dan viabilitas spermatozoa sapi Limousin selama penyimpanan pada refrigerator dalam pengencer CEP-2 dengan suplementasi kuning telur. Jurnal Kedokteran Hewan 7(1): 5 - 8, ISSN : 1978225X.

Garner, D.L., and E.S.E. Hafez. 2008. Spermatozoa and Plasma Semen. In Reproduction in Farm Animal. Hafez E.S.E. and B. Hafez (eds.). 7th ed. Lippincott \& Williams. Baltimore, Marryland, USA: 82-95.

Herdis. 2005. Optimalisasi inseminasi buatan melalui aplikasi teknologi laserpunktur pada domba Garut (Ovis aries). Disertasi. Institut. Pertanian Bogor. Bogor

Hafez, E.S.E. 2000. Semen Evaluation. In: Reproduction In Farm Animals. Edition. Lippincott Wiliams and Wilkins. Maryland. USA

Hoesni, F. 1997. Pengaruh Kadar Kuning Telur dalam Berbagai Pengencer terhadap Kualitas Spermatozoa Domba Pasca Pembekuan. Tesis. Program Pasca Sarjana Universitas Padjadjaran. Bandung.

Ismaya. 2014. Bioteknologi Inseminasi Buatan pada Sapi Potong. Gajah Mada University Prees. Yogyakarta.

Kartasudjana, R. 2001. Teknik Inseminasi Buatan. Departemen Pendidikan Nasional. Jakarta.

Parera, F., Z. Prihatini, D.F. Souhoka dan M. Rizal. 2009. Pemanfaatan Sari Wortel sebagai Pengenceran Alternatif Spermatozoa Epididimis Sapi Bali. J. Indon. Trop. Anim. Agric. 34 (1): 5056.

Rusdin dan K. Jum'at. 2000. Motilitas dan Recovery Sperma Domba dalam Berbagai Pengencer Selama Penyimpanan pada Suhu $5^{\circ} \mathrm{C}$. Jurusan Peternakan Fakultas Pertanian Universitas Tadulako. Palu. 
Rianto. 2004. Pemetaan sentra potensi unggulan komoditas peternakan dan perikanan. Laporan Akhir. Kerjasama Badan Perencanaan Pembangunan Daerah Kabupaten Blora dengan Fakultas Peternakan. Universitas Diponegoro. Semarang.

Salisbury, G.W. dan H.L.Van Denmark. 1985. Fisiologi Reproduksi dan Inseminasi Buatan pada Sapi. Penterjemah: DJANUAR, R. Gadjah Mada University Press. Yogyakarta. $274-302 ; 314-343 ; 350$ - 380; 568 586.

Susilawati, T., P. Srianto, Hermanto dan E.Yuliani. 2003. Inseminasi Buatan dengan Spermatozoa Beku Hasil Sexing pada Sapi untuk Mendapatkan Anak dengan Jenis Kelamin Sesuai Harapan. Laporan Penelitian. Fakultas Peternakan Universitas Brawijaya. Malang

Solihati, N., R. Idi, S.D. Rasad, M. Rizal, dan M. Fitriati. 2008. Kualitas spermatozoa cauda epididimis sapi peranakan
Ongole (PO) dalam pengencer susu, tris dan sitrat kuning telur pada penyimpanan $\quad 4-5 \quad{ }^{\circ} \mathrm{C}$. Animal Production. 10 (1): 22-29. ISSN: 14112027.

Siswanto. 2006. Kualitas Semen di dalam Pengencer Tris dan Natrium Sitrat dengan Berbagai Sumber Karbohidrat dan Level Gliserol pada Proses Kriopreservasi Semen Rusa Timor (Cervus timorensis). Tesis. Sekolah Pascasarjana. Institut Pertanian Bogor.

Toelihere, M.R. 1985. Inseminasi Buatan pada Ternak. Penerbit Angkasa. Bandung.

White, I. G. 1993. Lipid and Ca uptake of sperm in relation to cold shock and preservation: A review. Reprod. Fertil. Dev. 5: 639-658.

Widjaya, N. 2011. Fisiologi Reproduksi dan Inseminasi Buatan pada Sapi. Gajah Mada University Press. Yogyakarta. 